\title{
Age-dependent changes in phenotypes and candidate gene analysis in a polygenic animal model of Type II diabetes mellitus; NSY mouse
}

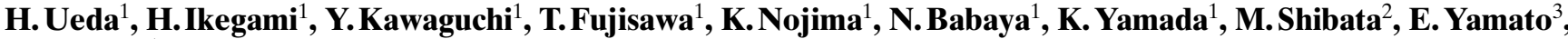 \\ T. Ogihara ${ }^{1}$ \\ ${ }^{1}$ Department of Geriatric Medicine, Osaka University Medical School, Osaka, Japan \\ ${ }^{2}$ Department of Health, Aichi-gakuin University, College of General Education, Aichi, Japan \\ ${ }^{3}$ Department of Nutrition and Physiological Chemistry, Osaka University Medical School, Osaka, Japan
}

\section{Abstract}

Aims/hypothesis. The Nagoya-Shibata-Yasuda (NSY) mouse closely mimics human Type II (non-insulin-dependent) diabetes mellitus in that the onset is age-dependent, the animals are not severely obese, and both insulin resistance and impaired insulin response to glucose contribute to disease development. The aim of this study was to clarify the influence of age on the pathogenesis of diabetes and to analyse a candidate gene for Type II diabetes in this strain. Methods. Several phenotypic characteristics related to diabetes mellitus were monitored longitudinally in male NSY and control C3H/He mice. The nucleotide sequence of Glut4, a candidate gene for Nidd1nsy (a susceptibility gene for Type II diabetes) on Chromosome 11, encoding insulin-sensitive glucose transporter, was determined in NSY and $\mathrm{C} 3 \mathrm{H}$ mice.

Results. Glucose intolerance worsened with age, and fasting blood glucose and fasting plasma insulin con- centration increased with age in NSY mice. Pancreatic insulin content increased until 24 weeks of age but then decreased at 48 weeks of age in NSY mice. The hypoglycaemic response to insulin was statistically significantly smaller in NSY than in $\mathrm{C} 3 \mathrm{H} / \mathrm{He}$ mice. The nucleotide sequence of GLUT4 cDNA was identical in NSY and $\mathrm{C} 3 \mathrm{H} / \mathrm{He}$ mice, but both were different from the sequence reported previously.

Conclusion/interpretation. Insulin secretion and insulin resistance, as well as ageing possibly play an important part in the disease development in NSY mice. A decline of pancreatic insulin content in older age might cause the relative insulin deficiency in this strain. Nucleotide sequencing suggests that Glut4 is unlikely to be a candidate gene for Nidd1nsy. [Diabetologia (2000) 43: 932-938]

Keywords NSY mouse, ageing, animal model, insulin resistance, glucose transporter 4 .
Type II (non-insulin-dependent) diabetes mellitus is a polygenic disease characterised by insulin resistance in muscle, fat and liver, and the failure of pancreatic beta cells to adequately compensate for this

Received: 10 November 1999 and in revised form: 11 February 2000

Corresponding author: $\mathrm{H}$. Ikegami, $\mathrm{MD}, \mathrm{PhD}$, Department of Geriatric Medicine, Osaka University Medical School, 2-2 Yamadaoka, Suita, Osaka 565-0871, Japan

Abbreviations: NSY mouse, Nagoya-Shibata-Yasuda mouse; Glut4, glucose transporter 4; i.p. GTT, intraperitoneal glucose tolerance test; QTL, quantitative trait loci; MLS, maximum lod score; Chr, chromosome. resistance $[1,2]$. Glucose tolerance is reported to be impaired with advancing age $[3,4]$. Deterioration of glucose tolerance can be due to impaired insulin secretion or impaired insulin action or both. The relative contribution of insulin deficiency and insulin resistance to the pathogenesis of age-related glucose intolerance is still controversial [5] because of the difficulty in doing longitudinal studies in humans. Longitudinal analysis of glucose tolerance in animal models with different degrees of glucose intolerance is one of the best ways to address this question.

The Nagoya-Shibata-Yasuda (NSY) mouse strain was established as an inbred animal model with spontaneous development of Type II diabetes, by selective breeding for glucose intolerance from out- 
bred Jcl:ICR mice [6]. The NSY mouse closely mimics human Type II diabetes in that the onset is agedependent, the animals are not severely obese, and both insulin resistance and impaired insulin response to glucose contribute to disease development [7]. Impaired insulin response to glucose is observed after 12 weeks of age in this strain, and this impairment progressively worsens with advancing age [7]. Although impaired insulin response to glucose seems to play an important part in the development of Type II diabetes in this strain, impaired insulin action possibly also contributes to glucose intolerance. The age-dependent development of diabetes suggests that ageing is an important factor contributing to glucose intolerance and related phenotypes in NSY mice.

The gene Nidd1nsy in the middle part of Chromosome (Chr) 11 shows strong evidence of linkage with a maximum lod score (MLS) of 9.50 for glucose intolerance [8]. A potential candidate gene for Nidd1nsy is Glut4 [9], which encodes the insulin-sensitive glucose transporter 4 (GLUT4). Glucose transporter 4 is of particular importance in glucose homeostasis because it mediates insulin-mediated glucose uptake in skeletal muscle, the main site of glucose disposal, and in adipose tissue [10-13]. Altered GLUT4 activity is suggested to be one of the factors responsible for decreased glucose uptake in muscle and adipose tissue in patients with Type II diabetes [14]. Moreover, the development of muscle insulin resistance and diabetes is reported in heterozygous GLUT4 knockout mice [15].

The aim of this study was to examine how diabetes-related phenotypes and ageing affect the development of diabetes mellitus in humans. We used an animal model of Type II diabetes and longitudinally monitored phenotypic characteristics related to diabetes in this model. Furthermore, to investigate the possible contribution of GLUT4 to the pathogenesis of diabetes in NSY mice, we determined the nucleotide sequence of GLUT4 cDNA in NSY and control $\mathrm{C} 3 \mathrm{H} / \mathrm{He}$ mice.

\section{Materials and methods}

We obtained originally three pairs of NSY mice (F36) from the Branch Hospital of Nagoya University School of Medicine. The colony of NSY mice was maintained in the animal facilities of Osaka University Medical School by brother-sister mating with selective breeding for glucose intolerance. We used C3H/He mice (Charles River Laboratories, Kanagawa, Japan) as a non-diabetic control strain. Osaka University Medical School Guidelines for the Care and Use of Laboratory Animals were followed. All mice were given a laboratory diet, MF (Oriental Yeast, Tokyo, Japan), containing 24.6\% protein, $5.6 \%$ fat, $3.1 \%$ fibre, $6.3 \%$ ash and $52.8 \%$ complex carbohydrate, and tap water ad libitum in an air-conditioned room $\left(22-25^{\circ} \mathrm{C}\right)$ with a 12 -h light:dark cycle.
Glucose tolerance test. Intraperitoneal glucose tolerance test (i.p. GTT) was done by injecting glucose $(2 \mathrm{~g} / \mathrm{kg}$ as $20 \%$ solution) intraperitoneally in overnight-fasted mice without anaesthesia at 4, 8, 12, 24, 36, 48 and 60 weeks of age. Blood samples were obtained from the tail vein. Blood glucose concentration was measured directly by glucose oxidase method using Glutest E (Kyoto Daiichi Kagaku, Kyoto, Japan) at 0, 30, 60, 90 and 120 min during i.p. GTT $[8,16]$. Area under the glucose curve (AUC) was also calculated according to the trapezoid rule from the glucose measurements at baseline ( $0 \mathrm{~min}), 30$, 60, 90 and $120 \mathrm{~min}(\mathrm{mmol} / \mathrm{l} \cdot \mathrm{min})$.

Measurement of fasting blood glucose and fasting plasma insulin concentrations. Fasting blood glucose and fasting plasma insulin concentrations were monitored in overnight-fasted mice at $8,12,24,36$ and 48 weeks of age. Blood glucose concentration was measured directly by glucose oxidase method using Glutest E. For measurement of insulin concentration whole blood $(300 \mu \mathrm{l})$ was collected from the orbital sinus and immediately placed on ice. Plasma was obtained by centrifugation. Plasma insulin was measured by RIA (ShionoRIA insulin, Shionogi, Osaka, Japan) using rat insulin (Novo Nordisk, Copenhagen, Denmark) as a standard [17].

Measurement of phenotypic characteristics and pancreatic insulin content. After anaesthetisation (pentobarbital $50 \mathrm{mg} / \mathrm{kg}$, i.p.), body weight and anal-nasal length were measured. Body mass index (BMI) was calculated as body weight (g) divided by the square of the anal-nasal length $(\mathrm{cm})$. The pancreas and epididymal fat pads were dissected and weighed. Insulin was extracted from the pancreas by acid ethanol method [18] and measured by RIA as described above.

Insulin tolerance test. Insulin tolerance test was done by injecting human insulin $(0.5 \mathrm{U} / \mathrm{kg}$; Humulin R, Eli Lilly, Indianapolis, Ind., USA) intraperitoneally in overnight-fasted $\mathrm{C} 3 \mathrm{H} / \mathrm{He}$ and NSY mice at 48 weeks of age. Blood samples were obtained from the tail vein. Blood glucose concentration was measured directly by glucose oxidase method using Glutest E at $0,15,30,45$ and $60 \mathrm{~min}$ during this test. Results are expressed as the percentage change from fasting blood glucose concentration.

Sequencing of GLUT4 cDNA. Total RNA was extracted from the muscle of NSY and C3H/He mice. The DNA sequence of the Glut4 gene of NSY and $\mathrm{C} 3 \mathrm{H} / \mathrm{He}$ mice was determined by PCR amplification of muscle cDNA as four overlapping segments, using primers based on the sequence of murine GLUT4 cDNA [19]. The resulting PCR products were subcloned into pT7Blue Vector (Novagen, Madison, Wis., USA), subjected to DNA sequencing and analysed on an ABI377 sequencer (Perkin-Elmer, Foster City, Calif., USA).

Statistical analysis. All results are expressed as means \pm SEM. Statistical analysis to compare NSY and $\mathrm{C} 3 \mathrm{H} / \mathrm{He}$ mice was done by Student's $t$ test and to compare the groups of animals at different ages ANOVA was used.

\section{Results}

Longitudinal changes in blood glucose and plasma insulin concentrations. Figure 1 shows the results of the glucose tolerance test in male NSY and $\mathrm{C} 3 \mathrm{H} / \mathrm{He}$ mice at 48 weeks of age. Fasting blood glucose and blood 


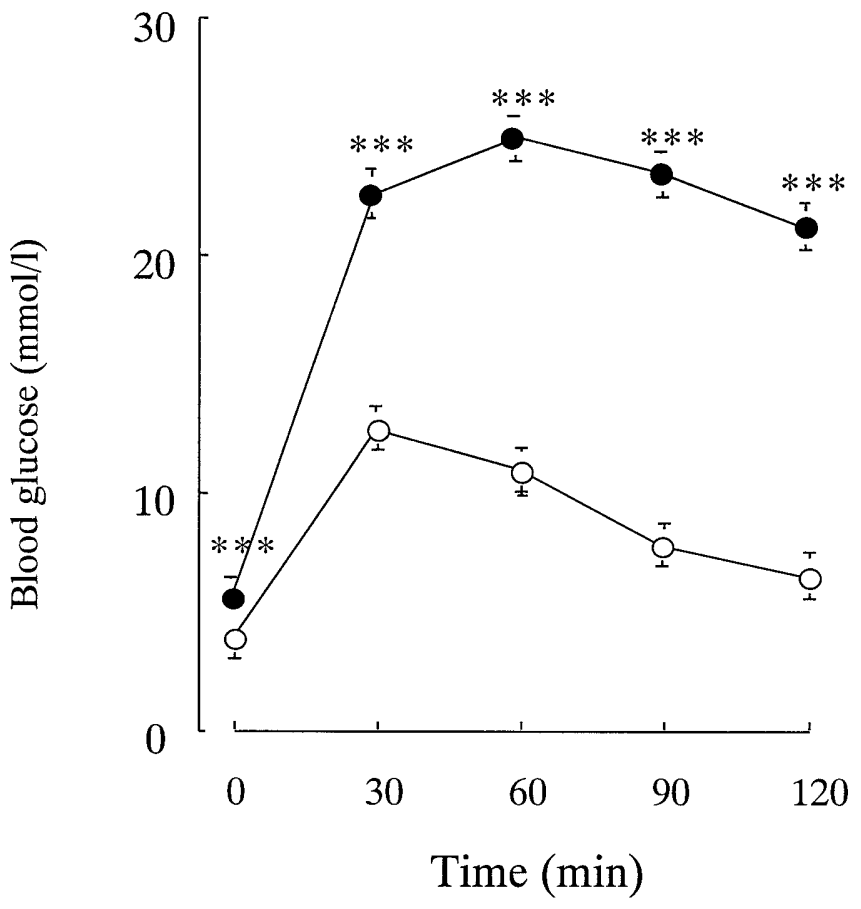

Fig. 1. Glucose tolerance test ( $2 \mathrm{~g} / \mathrm{kg}$ body weight) in male overnight-fasted $\mathrm{C} 3 \mathrm{H} / \mathrm{He}$ (open circles: $n=15$ ) and NSY (closed circles: $n=15$ ) mice at 48 weeks of age. Values are means \pm SEM. $* * * p<0.0001$ vs $\mathrm{C} 3 \mathrm{H} / \mathrm{He}$ mice

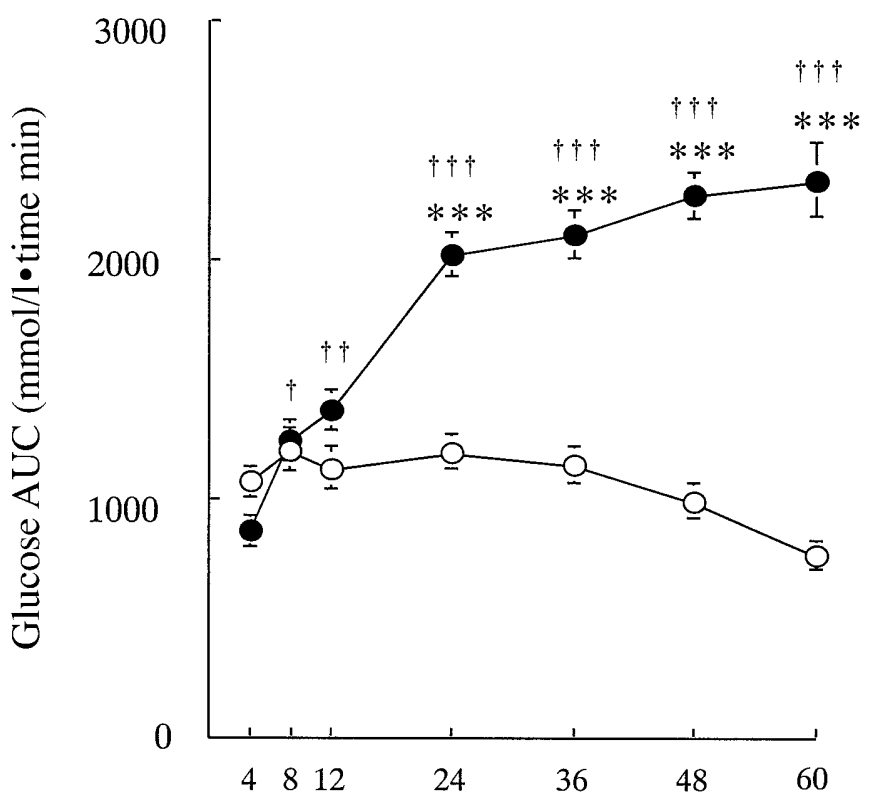

Weeks of age

Fig. 2. Glucose area under the curve $(\mathrm{mmol} / \mathrm{l} \cdot \mathrm{min})$ in male, overnight-fasted $\mathrm{C} 3 \mathrm{H} / \mathrm{He}$ (open circles: $n=5-15$ ) and NSY (closed circles: $n=9-15$ ) mice from 4 to 60 weeks of age. Values are means \pm SEM. $* * * p<0.0001$ vs male $\mathrm{C} 3 \mathrm{H} / \mathrm{He}$ mice; $\dagger p<0.01, \dagger \dagger p<0.001, \uparrow \dagger \dagger p<0.0001$ vs NSY mice at 4 weeks of age
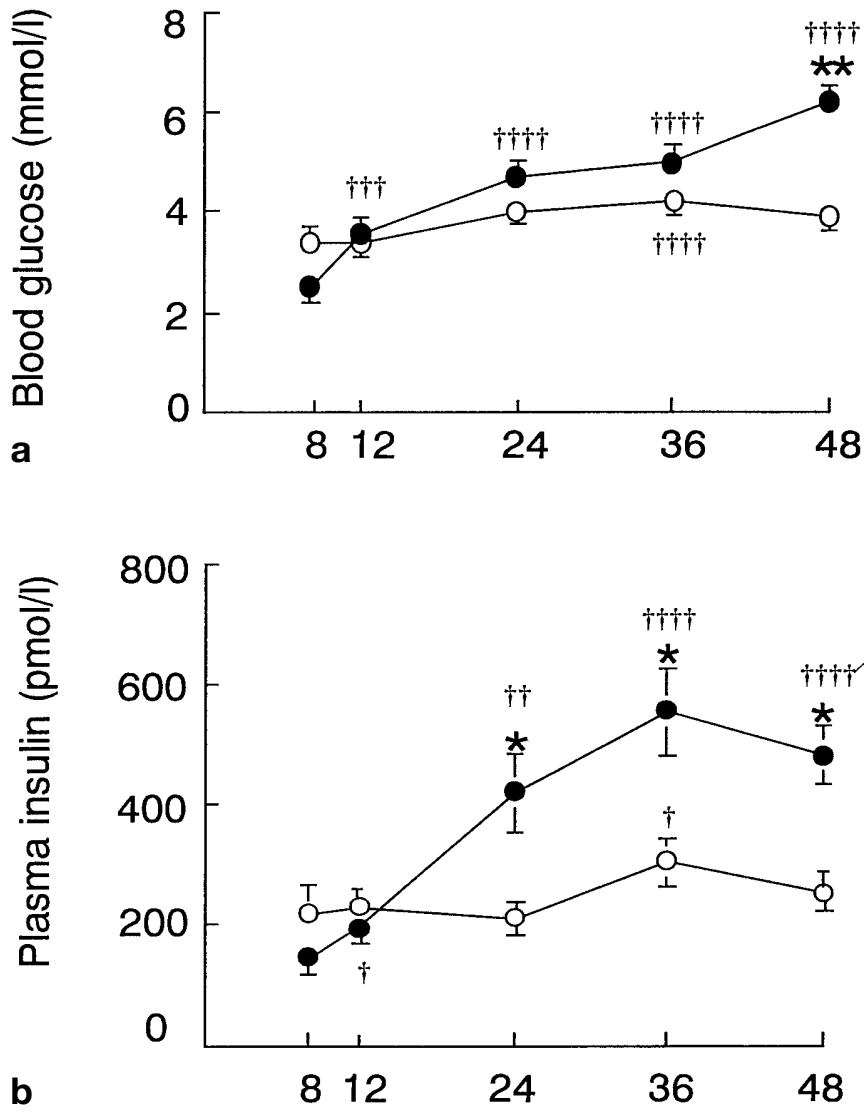

Weeks of age

Fig. 3. Longitudinal analysis of fasting blood glucose concentration (a) and plasma insulin concentration (b) in male, overnight-fasted $\mathrm{C} 3 \mathrm{H} / \mathrm{He}$ (open circles: $n=5-7$ ) and NSY (closed circles: $n=5-9$ ) mice from 8 to 48 weeks of age. Values are means \pm SEM. ${ }^{*} p<0.05 * * p<0.001$ vs male $\mathrm{C} 3 \mathrm{H} / \mathrm{He}$ mice; $\dagger p<0.05, \dagger \dagger p<0.01, \uparrow \dagger \dagger p<0.001,+\dagger \dagger \dagger p<0.0001$ vs 8 weeks of age in each strain

glucose concentrations after injection of glucose were significantly higher in NSY mice than in $\mathrm{C} 3 \mathrm{H} / \mathrm{He}$ mice $(p<0.0001)$.

Figure 2 shows glucose area under the curve (glucose AUC) of i.p. GTT at various ages between 4 and 60 weeks of age. No significant difference was observed in glucose AUC of male NSY and $\mathrm{C} 3 \mathrm{H} / \mathrm{He}$ mice at 4 weeks of age $(878 \pm 61$ and $1083 \pm 53$ $(\mathrm{mmol} / \mathrm{l} \cdot \mathrm{min})$, respectively). Glucose intolerance significantly worsened with age in NSY mice but not in $\mathrm{C} 3 \mathrm{H} / \mathrm{He}$ mice. Glucose AUC at 24, 36, 48 and 60 weeks of age in NSY mice was also significantly higher than at 8 weeks of age $(p<0.0001)$. Glucose AUC at 24, 36, 48 and 60 weeks of age in NSY mice was also significantly higher than at 12 weeks of age $(p<0.0001)$. Furthermore, glucose AUC at 60 weeks of age in NSY mice was also significantly higher than at 24 weeks of age $(p<0.05)$.

Figure 3 shows the longitudinal changes in fasting blood glucose and plasma insulin concentrations. 


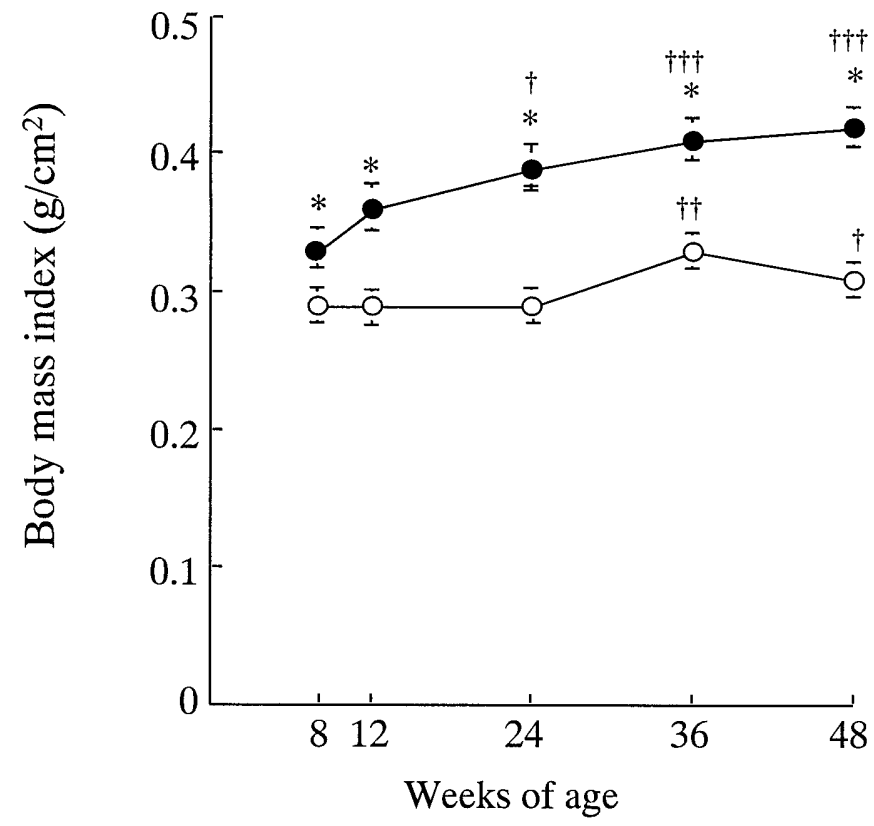

Fig. 4. Body mass index changes in $\mathrm{C} 3 \mathrm{H} / \mathrm{He}$ (open circles: $n=5-6)$ and NSY (closed circles: $n=5-8$ ) mice from 8 to 48 weeks of age. Values are means \pm SEM. ${ }^{*} p<0.001$ vs $\mathrm{C} 3 \mathrm{H} /$ He mice; $\dagger p<0.05, \dagger \dagger p<0.001, \dagger \dagger \dagger p<0.0001$ vs 8 weeks of age in each strain

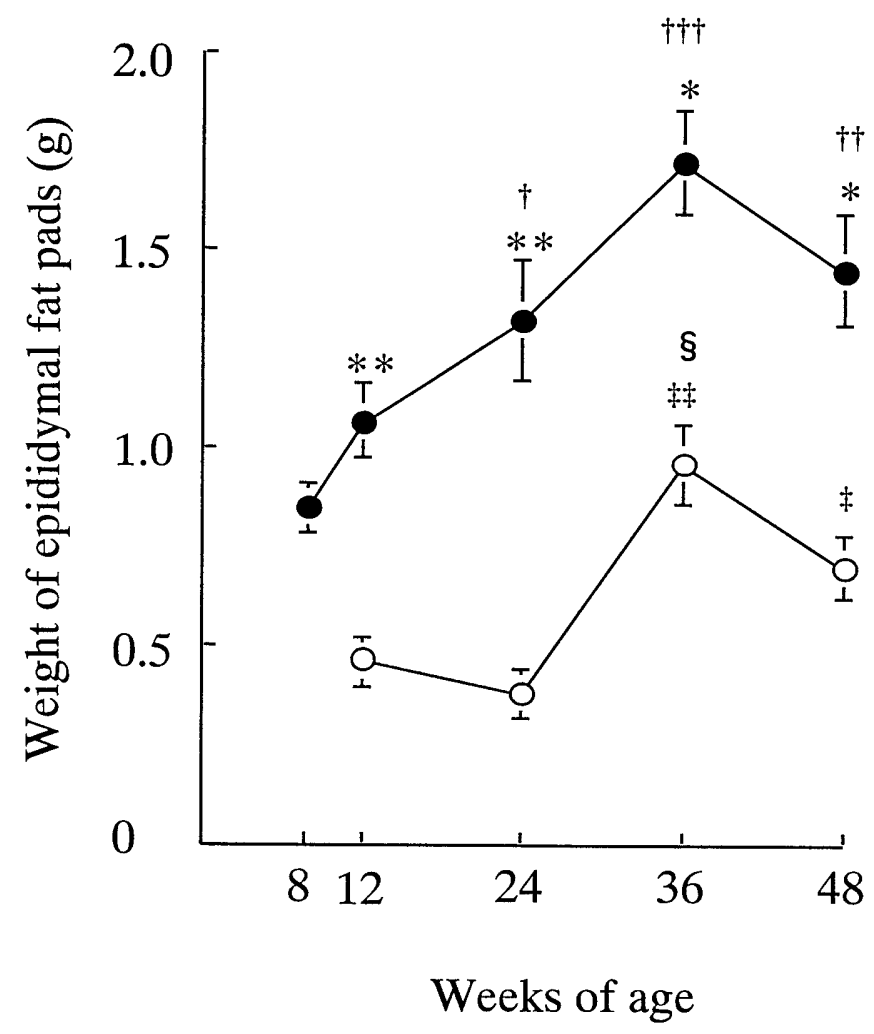

Fig.5. Changes of weight of epididymal fat pads in $\mathrm{C} 3 \mathrm{H} / \mathrm{He}$ (open circles: $n=5-6$ ) and NSY (closed circles: $n=5-8$ ) mice from 8 to 48 weeks of age. Values are means \pm SEM. ${ }^{*} p<0.01$ $* * p<0.001$ vs $\mathrm{C} 3 \mathrm{H} / \mathrm{He}$ mice; $\dagger p<0.05, \quad \dagger \dagger p<0.01$, $\dagger \dagger \dagger p<0.0001$ vs NSY mice at 8 weeks of age; $\ddagger p<0.05$, $\$ \ddagger p<0.01$ vs $\mathrm{C} 3 \mathrm{H} / \mathrm{He}$ mice at 12 weeks of age; $\S \mathrm{p}<0.05$ vs $\mathrm{C} 3 \mathrm{H} / \mathrm{He}$ mice at 48 weeks of age
Table 1. Phenotypic characterisation of male $\mathrm{C} 3 \mathrm{H} / \mathrm{He}$ and NSY mice at 8 weeks of age

\begin{tabular}{|c|c|c|c|}
\hline & $\begin{array}{l}\mathrm{C} 3 \mathrm{H} / \mathrm{He} \text { mice } \\
n=5-6\end{array}$ & $\begin{array}{l}\text { NSY mice } \\
n=5-6\end{array}$ & $p$ \\
\hline Blood glucose $(\mathrm{mmol} / \mathrm{l})$ & $3.4 \pm 0.1$ & $2.5 \pm 0.1$ & NS \\
\hline Plasma insulin (pmol/l) & $218 \pm 21$ & $144 \pm 5.1$ & NS \\
\hline $\mathrm{BMI}\left(\mathrm{g} \cdot \mathrm{cm}^{-2}\right)$ & $0.29 \pm 0.07$ & $0.33 \pm 0.05$ & $<0.001$ \\
\hline $\begin{array}{l}\text { Weight of epididymal fat } \\
\text { pads }(\mathrm{g})\end{array}$ & ND & $0.85 \pm 0.05$ & - \\
\hline 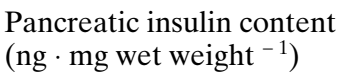 & $34.3 \pm 6.3$ & $33.8 \pm 4.3$ & NS \\
\hline
\end{tabular}

Values are means \pm SEM. NS: not significant. ND: not done

Fasting blood glucose concentration in NSY mice increased continuously with age. In contrast, fasting blood glucose concentration in $\mathrm{C} 3 \mathrm{H} / \mathrm{He}$ mice did not differ significantly among 8, 12, 24 and 48 weeks of age, except for a significant increase at 36 weeks of age. Fasting blood glucose was significantly higher in NSY mice than in $\mathrm{C} 3 \mathrm{H} / \mathrm{He}$ mice at 48 weeks of age $(p<0.001)$. Fasting plasma insulin concentration in NSY mice increased with age, whereas in $\mathrm{C} 3 \mathrm{H} / \mathrm{He}$ mice it was stable at all ages, except for a significant increase at 36 weeks of age. Fasting plasma insulin concentration was comparable between the two strains at 8 and 12 weeks of age. Fasting plasma insulin in NSY mice was significantly higher than in $\mathrm{C} 3 \mathrm{H} / \mathrm{He}$ mice at $24(p<0.05), 36(p<0.05)$ and 48 $(p<0.05)$ weeks of age.

Body mass index and weight of epididymal fat pads. Figure 4 shows the longitudinal changes in BMI. Up to 48 weeks of age BMI of NSY increased continuously. Until 24 weeks of age BMI of $\mathrm{C} 3 \mathrm{H} / \mathrm{He}$ mice did not change with age and was slightly increased at 36 and 48 weeks of age. At all ages BMI in NSY mice was significantly higher than in $\mathrm{C} 3 \mathrm{H} / \mathrm{He}$ mice $(p<0.001)$. Figure 5 shows the weight of epididymal fat pads. Weight of epididymal fat pads increased in NSY mice with age, whereas in $\mathrm{C} 3 \mathrm{H} / \mathrm{He}$ mice it was stable until 24 weeks of age with a slight increase at 36 and 48 weeks of age. Weight of epididymal fat pads did not significantly differ between 36 and 48 weeks of age in NSY mice. Weight of epididymal fat pads was significantly decreased $(p<0.05)$ in $\mathrm{C} 3 \mathrm{H} / \mathrm{He}$ mice at 48 weeks of age compared with 36 weeks of age. Weight of epididymal fat pads was significantly greater in NSY mice than in $\mathrm{C} 3 \mathrm{H} / \mathrm{He}$ mice after 12 weeks of age $(p<0.01)$. All baseline data (8-week-old animals) for fasting blood glucose, fasting plasma insulin, BMI, epididymal fat pad weight and pancreatic insulin content are in Table 1.

Pancreatic insulin content. Pancreatic insulin content in NSY mice was significantly increased at 24, 36 and 48 weeks of age from the baseline value, being 


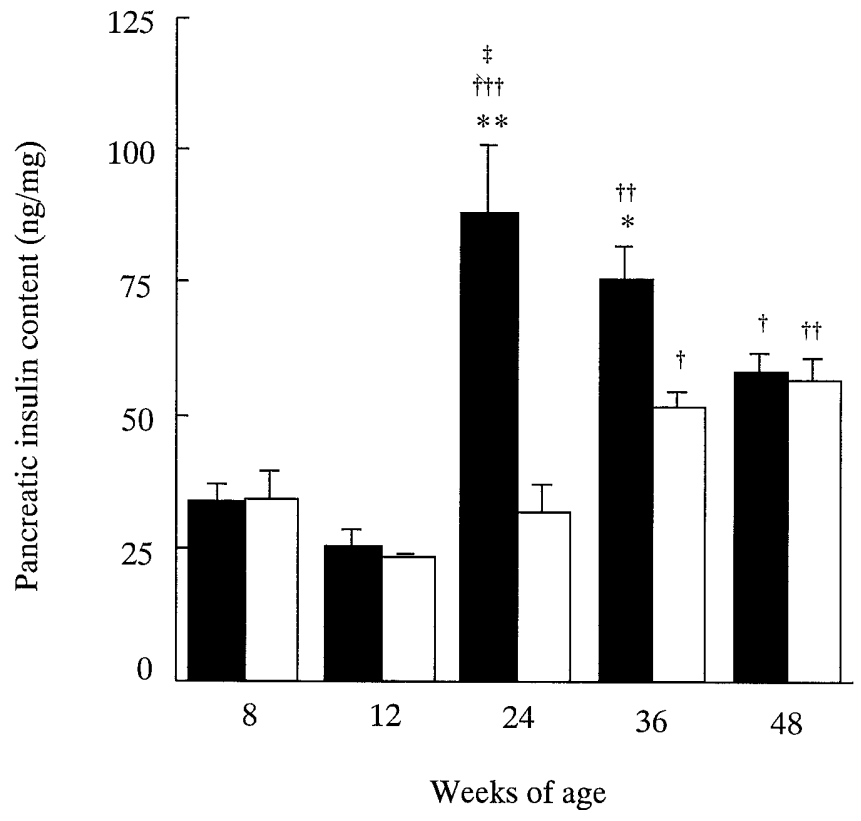

Fig. 6. Longitudinal analysis of pancreatic insulin content in male $\mathrm{C} 3 \mathrm{H} / \mathrm{He}$ (open bars) and NSY (closed bars) mice from 8 to 48 weeks of age. $n=5-6$ in each group. Values are mean$\mathrm{s} \pm$ SEM. $* p<0.05 * * p<0.01$ vs $\mathrm{C} 3 \mathrm{H} / \mathrm{He}$ mice; $\dagger p<0.05$, $\dagger \dagger p<0.01$, $\dagger \dagger \dagger p<0.0001$ vs 8 weeks of age in each strain; $\ddagger p<0.01$ vs NSY mice at 48 weeks of age

the highest at 24 weeks of age and decreasing gradually thereafter (Fig. 5). Pancreatic insulin content in $\mathrm{C} 3 \mathrm{H} / \mathrm{He}$ mice, in contrast, did not change up to 24 weeks of age, with a significant increase at 36 and 48 weeks of age compared with 8 weeks of age. Pancreatic insulin content was comparable between the two strains at 8,12 and 48 weeks of age but was significantly higher in NSY mice than in $\mathrm{C} 3 \mathrm{H} /$ He mice at $24(p<0.01)$ and $36(p<0.05)$ weeks of age.

Insulin tolerance test. Insulin tolerance test was done in male $\mathrm{NSY}$ and $\mathrm{C} 3 \mathrm{H} / \mathrm{He}$ mice at 48 weeks of age (Fig. 6). The hypoglycaemic response to insulin at 30, 45 and 60 min after its injection was significantly smaller in NSY than in $\mathrm{C} 3 \mathrm{H}$ mice. The hypoglycaemic response to insulin at $60 \mathrm{~min}$ after its injection was significantly smaller in NSY $(61.8 \pm 3.7 \%$ of fasting glucose; $n=11$ ) than in $\mathrm{C} 3 \mathrm{H}$ mice $(47.1 \pm 2.3 \%$ of fasting glucose; $n=12, p<0.01)$.

Nucleotide sequence of GLUT4 cDNA. The nucleotide sequence of GLUT4 cDNA in the NSY mouse was found to be the same as in the $\mathrm{C} 3 \mathrm{H} / \mathrm{He}$ mouse. The nucleotide sequence in these two strains, however, was different from the previously reported sequence in 129/v strain [19]. This difference in nucleotide sequence led to the substitution of six amino acids in the predicted amino acid sequence compared with the previously reported one (Table 2 ). All these

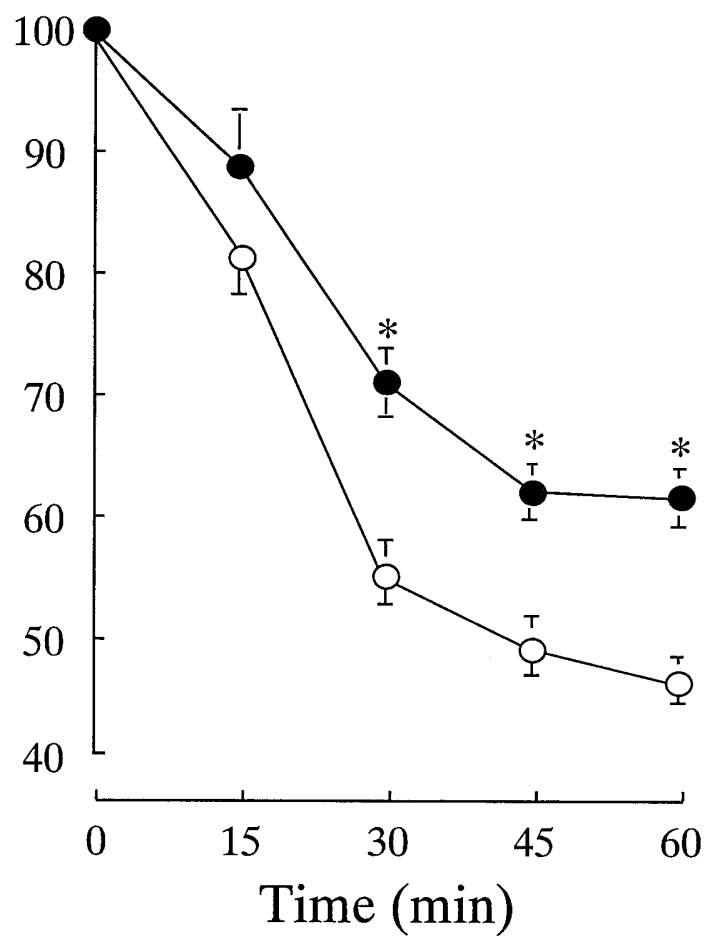

Fig. 7. Insulin tolerance test $(0.5 \mathrm{U} / \mathrm{kg}$ body weight $)$ in male overnight-fasted $\mathrm{C} 3 \mathrm{H} / \mathrm{He}$ (open circles: $n=12$ ) and NSY (closed circles: $n=11$ ) mice at 48 weeks of age. Results are expressed as the percentage change from fasting blood glucose concentration. Values are means $\pm \mathrm{SEM}$. ${ }^{*} p<0.01$ vs $\mathrm{C} 3 \mathrm{H} / \mathrm{He}$ mice

six amino acids were conserved in human [20] and rat [21] GLUT4, but not in murine glucose transporter $1[19]$.

\section{Discussion}

Our previous report showed that NSY mice develop Type II diabetes in an age-dependent manner [7]. Ageing plays an important part in the development of diabetes in humans [3] as well as in NSY mice. Glucose intolerance worsened with age in NSY mice. In control $\mathrm{C} 3 \mathrm{H} / \mathrm{He}$ mice, on the other hand, glucose tolerance was stable even at older ages. Fasting plasma insulin concentration and pancreatic insulin content rose with age and then slightly decreased at an older age in NSY mice. In control $\mathrm{C} 3 \mathrm{H} / \mathrm{He}$ mice, in contrast, fasting plasma insulin concentration was stable at all ages, except for a significant increase at 36 weeks of age, and pancreatic insulin content was significantly increased at 36 and 48 weeks of age. These observations suggest that the islets of NSY mice retain the ability to synthesise insulin to compensate for insulin resistance up to 36 weeks of age, but the ability to synthesise insulin is decreased or exhausted at 48 weeks of age, leading to the increase of fasting blood glucose concentration. The longitudinal 
Table 2. Predicted amino acid sequence of GLUT4 in NSY, C3H/He and 3T3L1 cell line (mouse 129/v)

a) MPSGFQQIGSD--DGEPPRQRVTGTLVLAVFSAVLGSLQFGYNIGVINAP

b) ---------------------------------------------------------

c)

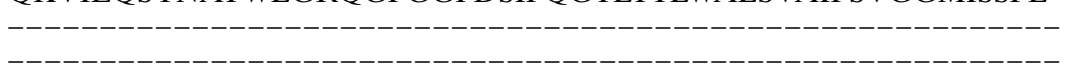

IGIISQWLGRKRAMLANNVLAVLGGALMGLANAAASYEILILGRFLIGAY

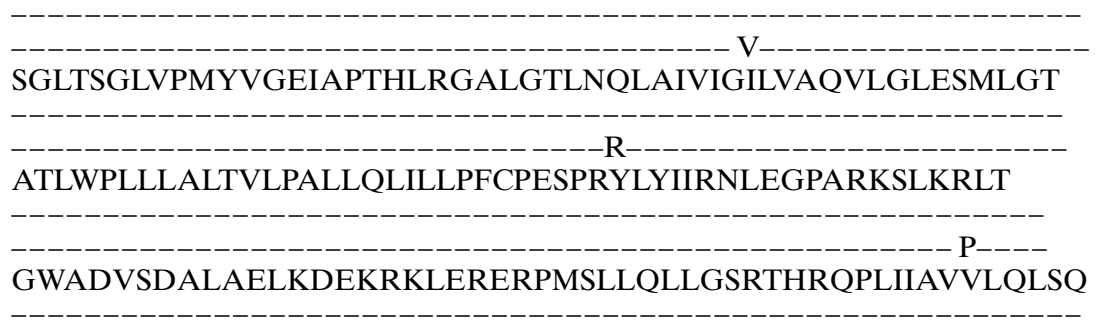

QLSGINAVFYYSTSIFESAGVGQPAYATIGAGVVNTVFTLVSVLLVERAG

RRTLHLLGLAGMCGCAILMTVALLLLERVPAMSYVSIVAIFGFVAFFEIG

PGPIPWFIVAELFSQGPRPAAMAVAGFSNWTCNFIVGMGFQYVADAMGPY

----------------------------------------------------------

VFLLFAVLLLGFFIFTFLKVPETRGRTFDQISAAFRRTPSLLEQEVKPST

\section{ELEYLGPDEND}

-ー-ー-ー-ー-ー---

(a) NSY mouse, (b) $\mathrm{C} 3 \mathrm{H} / \mathrm{He}$ mouse, (c) 3T3L1 cell line (mouse 129/v, from reference 19)

characteristics of hyperinsulinaemia as observed in NSY mice were also reported in $\mathrm{C} 57 \mathrm{Bl} / \mathrm{Ks} \mathrm{db} / \mathrm{db}$ mice. In this strain, insulin concentrations rose six to ten times above normal at 3 to 6 weeks of age, and then the hyperinsulinaemia waned to below normal concentrations between 3 and 6 months of age [22]. In NSY mice, hyperinsulinaemia was much less pronounced but the hyperinsulinaemic state lasted longer. This phenomenon could reflect the delayed expression of timed genes conveying susceptibility to diabetes in NSY mice, acting through insulin deficiency, insulin resistance, or both. Indeed, longitudinal quantitative trait loci (QTL) mapping in our previous study showed that both maximum lod score (MLS) and interval of mapped loci changed and shifted with age [8]. Nagoya-Shibata-Yasuda mice might be useful to identify genes conveying susceptibility to diabetes whose expression is affected by ageing.

Insulin tolerance test showed that insulin action was impaired in NSY mice (Fig. 6). In our previous study [7], the existence of insulin resistance was only suggested by fasting hyperinsulinaemia, but this was confirmed in the present study. Thus, insulin resistance together with functional changes in pancreatic
Dash indicates identity with NSY sequence. The nucleotide sequence data reported in this paper will appear in the DDBJ, EMBL and GenBank nucleotide sequence databases with the following accession number: AB008453

beta cells appear to play an important part in the development of diabetes in NSY mice.

Body mass index of NSY mice was significantly greater than in $\mathrm{C} 3 \mathrm{H} / \mathrm{He}$ mice. In addition, epididymal fat pad weight in NSY mice was significantly greater than in $\mathrm{C} 3 \mathrm{H} / \mathrm{He}$ mice. These characteristics together with insulin resistance as shown by insulin tolerance test are similar to those observed in human patients with insulin resistance syndrome $[23,24]$ in which visceral fat accumulation is a risk factor for glucose intolerance, even in patients with mild obesity [25]. Note that, an age-dependent increase in BMI and epididymal fat pad weight was similarly observed in both strains although the degree of increase was different between the two strains. The age-dependent increase in BMI and accumulation of epididymal fat pads, therefore, seem to be caused by age per se but not by a difference in genetic background between the two strains. These characteristics are similar to those observed in non-diabetic humans [26]. The greater BMI and fat pad accumulation in NSY mice, on the other hand, might reflect the different genetic background from that of $\mathrm{C} 3 \mathrm{H} / \mathrm{He}$ mice. The slight, but significant, decrease in weight of epididymal fat 
in $\mathrm{C} 3 \mathrm{H} / \mathrm{He}$ mice at 48 weeks of age compared with that at 36 weeks of age could have contributed to the reduced risk for glucose intolerance in this strain.

As mentioned above, the genetic background of the NSY mouse seems to contribute in this strain to the greater BMI and fat pad accumulation which are associated with insulin resistance and glucose intolerance. A candidate gene for these characteristics is Glut4, encoding the insulin-sensitive glucose transporter GLUT4. A defect in GLUT4 function has been reported to result in insulin resistance and diabetes [15]. The murine Glut4 gene is located in the central region of chromosome 11 , where a strong susceptibility gene for Type II diabetes, Nidd1nsy, has been mapped in our whole genome scan in the NSY mouse [8]. The highest MLS which Nidd1nsy showed for glucose intolerance was 9.52, whereas the highest MLS which the second strongest locus, Nidd2nsy, showed for glucose intolerance was 4.88 [8]. Thus, we considered that Nidd1nsy is the most important locus in the disease development, and we focused on the analysis of a candidate gene for Nidd1nsy. We therefore determined the nucleotide sequence of Glut4 in the NSY mouse and control strains. The nucleotide sequence of Glut4 was identical in NSY and $\mathrm{C} 3 \mathrm{H} / \mathrm{He}$ mice, suggesting that allelic variation in Glut4 is unlikely to be responsible for the Nidd1nsy effect. Although the nucleotide sequence of GLUT4 cDNA was identical in NSY and $\mathrm{C} 3 \mathrm{H} / \mathrm{He}$ mice, the nucleotide sequence in these strains was different from that of the previously reported cDNA sequence for murine GLUT4. The reason for the difference in Glut4 sequence in NSY and $\mathrm{C} 3 \mathrm{H} / \mathrm{He}$ mice from the previously reported sequence is not clear. The previously reported sequence of cDNA was from a cell line derived from $129 / \mathrm{v}$ mice [19]. It is possible that the sequence of the Glut4 gene has changed during the establishment or maintenance of the cell line. Another possibility is a strain difference. Although functional analysis of GLUT4 using two different GLUT4 is necessary to clarify how it affects the diabetic phenotype, 129/v mice were not reported as an animal model of diabetes [22]. GLUT4 of 129/v is therefore unlikely to have a strong functional defect.

In summary, insulin secretion and insulin resistance, as well as ageing, possibly play an important part in the disease development in NSY mice. A decline of pancreatic insulin content at older age could cause the relative insulin deficiency in this strain. Sequence analysis suggests that Glut4 is unlikely to be a candidate gene for Niddlnsy.

Acknowledgements. This study was supported by a Grant-inAid for Scientific Research from the Ministry of Education, Science, Sports and Culture, and Health Sciences Research Grants (Research on Human Genome and Gene Therapy) from the Ministry of Health and Welfare, Japan.

We thank Y. Ueno and M. Moritani for their technical assistance.

\section{References}

1. Weir GC, Leahy JL (1994) Pathogenesis of non-insulin-dependent (type II) diabetes mellitus. In: Kahn CR, Weir GC (eds) Joslin's Diabetes Mellitus XIII. Lea \& Febiger, Pennsylvania, pp 240-264

2. Brüning JC, Winnay J, Bonner-Weir S, Taylor SI, Accili D, Kahn CR (1997) Development of a novel polygenic model of NIDDM in mice heterozygous for IR and IRS-1 null alleles. Cell 88: 561-572

3. Davidson MB (1979) The effect of ageing on carbohydrate metabolism: a review of the English literature and practical approach to the diagnosis of diabetes mellitus in the elderly. Metabolism 28: 688-705

4. Higgins J, Proctor D, Denyer G (1999) Aging changes tissue-specific glucose metabolism in rats. Metabolism 48: 1445-1449

5. Ferrannini E, Vichi S, Beck-Nielsen H et al. (1996) Insulin action and age. Diabetes 45: 947-953

6. Shibata M, Yasuda B (1980) New experimental congenital diabetic mice (N. S. Y. mice). Tohoku J Exp Med 130: 139-142

7. Ueda H, Ikegami H, Yamato E et al. (1995) The NSY mouse: a new animal model of spontaneous NIDDM with moderate obesity. Diabetologia 38: 503-508

8. Ueda H, Ikegami H, Kawaguchi Y et al. (1999) Genetic analysis of late-onset type 2 diabetes in a mouse model of human complex trait. Diabetes 48: 1168-1174

9. Hogan A, Heyner S, Charron MJ et al. (1991) Glucose transporter gene expression in early mouse embryos. Development 113: 363-372

10. Stephens JM, Pilch PF (1995) The metabolic regulation and vesicular transport of GLUT4, the major insulin-responsive glucose transporter. Endocr Rev 16: 529-546

11. Gould GW, Holman GD (1993) The glucose transporter family: structure, function and tissue-specific expression. Biochem J 295: 329-341

12. Thorens B, Charron MJ, Lodish HF (1990) Molecular physiology of glucose transporters. Diabetes Care 13: 209-218

13. Mueckler M (1990) Family of glucose transporter genes. Implications for glucose homeostasis and diabetes. Diabetes 39: 6-11

14. Kahn BB (1992) Alterations in glucose transporter expression and function in diabetes: mechanisms for insulin resistance. J Cell Biochem 48: 122-128

15. Stenbit AE, Tsao TS, Li J et al. (1997) GLUT4 heterozygous knockout mice develop muscle insulin resistance and diabetes. Nat Med 3: 1096-1101

16. Lewis BD (1992) Laboratory evaluation of the Glucocard blood glucose test meter. Clin Chem 38: 2093-2095

17. Yamato E, Ikegami H, Tahara Y et al. (1993) Cellular mechanism of glyburide-induced insulin gene expression in isolated rat islets. Biochem Biophys Res Commun 197: 957-964

18. McEvoy RC (1984) Tissue culture of fetal rat pancreatic islets: quantitation of changes in the number of islet cells during culture. In: Larner J, Pohl SL (eds). Methods in Diabetes Research I Part A. John Wiley, New York, p 236

19. Kaestner KH, Christy RJ, McLenithan JC at al. (1989) Sequence, tissue distribution, and differential expression of mRNA for a putative insulin-responsive glucose transporter in mouse 3T3-L1 adipocytes. Proc Natl Acad Sci USA 86: 3150-3154

20. Buse JB, Yasuda K, Lay TP at al. (1992) Expression and regulation of the human GLUT4/muscle-fat facilitative glucose transporter gene in transgenic mice. J Biol Chem 267: 11673-11676

21. James DE, Strube M, Mueckler M (1989) Molecular cloning and characterization of an insulin-regulatable glucose transporter. Nature 338: 83-87

22. Shafrir E (1990) Diabetes in Animals. In: Rifkin H, Porte D Jr (eds) Ellenberg and Rifkin's diabetes mellitus: theory and practice, 4th edn. Elsevier, Amsterdam, pp 299-340

23. Reaven GM (1988) Banting lecture 1988. Role of insulin resistance in human disease. Diabetes 37: 1595-1607

24. DeFronzo RA, Ferrannini E (1991) Insulin resistance. A multifaceted syndrome responsible for NIDDM, obesity, hypertension, dyslipidemia, and atherosclerotic cardiovascular disease. Diabetes Care 14: 173-194

25. Fujioka S, Matuzawa Y, Tokunaga K, Tarui S (1987) Contribution of intra-abdominal fat accumulation to the impairment of glucose and lipid metabolism in human obesity. Metabolism 36: 54-59

26. Iozzo P, Beck-Nielsen H, Laakso M et al. (1999) Independent influence of age on basal insulin secretion in non diabetic humans. J Clin Endocrinol Metab 84: 863-868 